\title{
EFFECT OF ACTIVATED FLUX AND NITROGEN ADDITION ON THE BEAD GEOMETRY OF BORATED STAINLESS-STEEL GTA WELDS
}

\author{
VPLIV AKTIVIRANEGA TOPILA IN DODATKA DUŠIKA NA \\ GEOMETRIJO KOPELI PRI GTA ZVARIH BORIRANEGA \\ NERJAVNEGA JEKLA
}

\author{
Guttikonda Raja Kumar', Gabbita Durga Janaki Ram², Sajja Rama Koteswara Rao ${ }^{3}$ \\ ${ }^{1}$ Swarna Barathi Institute of Science and technology, Khammam, T. S., 507002, India \\ 2IIT Madras, Department of Metallurgical \& Materials Engineering, Chennai 600036, India \\ ${ }^{3}$ S.S.N. College of Engineering, Department of Mechanical Engineering, Chennai 603110, India \\ rajkumardotcom@yahoo.com \\ Prejem rokopisa - received: 2015-03-05; sprejem za objavo - accepted for publication: 2015-05-14
}

doi: $10.17222 / \mathrm{mit} .2015 .052$

\begin{abstract}
Borated stainless steels (304B) are used in nuclear power plants as control rods, shielding material, spent-fuel storage racks and transportation casks as they have a high capacity to absorb thermal neutrons. In this study, bead-on-plate welds were made on 10 -mm-thick 304B plates using gas tungsten arc welding with Ar and Ar+2\% nitrogen as the shielding gases, activated-flux GTA and electron-beam welding processes. The effects of the activated flux and nitrogen addition to the weld metal through the shielding gas, on the microstructure, bead geometry and mechanical properties were investigated. Activated-flux GTA welding and electron-beam welding substantially enhanced the depth of penetration and the aspect ratio compared to the other processes. Full-penetration welds were obtained in a single pass using activated-flux GTA and EB welding. The fusion-zone (FZ) microstructure of an activated GTA weld exhibits a columnar dendritic structure with eutectic borides in interdendritic regions, while a fine equiaxed dendritic structure was noticed in EB welds. GTA, nitrogen-added GTA and activated-flux GTA welds exhibited a partially melted zone adjacent to the fusion zone, with the activated-flux GTAW process resulting in a significantly thinner partially melted zone (PMZ). No PMZ was noticed in the EB welds. All the welds exhibited a high joint efficiency and impact toughness equal to those of the base material. It is concluded that the activated-flux GTA and EB welding processes are advantageous due to the use of a low heat input and failure location.
\end{abstract}

Keywords: borated stainless steels, bead geometry, activated flux, GTAW, partially melted zone, nitrogen

Borirana nerjavna jekla (304B) se uporabljajo v nuklearnih elektrarnah kot kontrolne palice, zaščitni material, nosilci shranjeval za izrabljene palice in za transportne sode, saj imajo sposobnost velike absorbcije termičnih nevtronov. V tej študiji so bili izdelani okrogli in ploščati zvari na $10 \mathrm{~mm}$ debelih ploščah iz 304B, z uporabo TIG varjenja v zaščitni atmosferi iz Ar $+2 \%$ dušika, $\mathrm{z}$ aktiviranim talilom GTA in varjenjem z elektronskim curkom. Preiskovan je bil vpliv aktiviranega talila in dodatka dušika v zvar s pomočjo zaščitnega plina, na mikrostrukturo, geometrijo kopeli in mehanske lastnosti. Varjenje z aktiviranim talilom GTA in varjenje $\mathrm{z}$ elektronskim curkom, občutno povečata globino penetracije in razmerje, v primerjavi z drugimi procesi. Z uporabo aktiviranega talila GTA in z varjenjem z elektronskim curkom je bila dosežena popolna penetracija zvarov. Mikrostruktura cone zlivanja (FZ) pri zvaru z aktiviranim talilom GTA, kaže stebrasto dendritno strukturo z evtektičnimi boridi $\mathrm{v}$ meddendritnih področjih, medtem ko je bila pri zvarih z elektronskim curkom opažena struktura z drobnimi enakoosnimi dendriti. Zvari GTA, GTA z dodanim dušikom in GTA z aktiviranim talilom, so kazali delno raztaljena področja okrog področja zlivanja ter z močno stanjšano delno staljeno področje (PMZ) pri postopku z aktiviranim talilom GTA. V zvarih z elektronskim curkom ni bilo opaziti PMZ. Vsi zvari so pokazali veliko učinkovitost spoja in udarno žilavost, ki je enaka kot pri osnovnem materialu. Ugotovljeno je, da imata varjenje z aktiviranim talilom GTA in varjenje z elektronskim snopom, prednost zaradi uporabe majhnega vnosa toplote in zaradi možnosti lokacije napak.

Ključne besede: borirano nerjavno jeklo, geometrija kopeli, aktivirano talilo, GTAW, delno staljeno področje, dušik

\section{INTRODUCTION}

Borated stainless steel 304B is an austenitic-type stainless steel containing $0.2 \%$ to $2.25 \%$ boron; it is widely used in nuclear industries for various applications. These applications involve storage of spent nuclear fuel in the forms of long-term storage tanks or caskets, transportation baskets and control rods. ${ }^{1,2}$ The objective of developing these steels is to absorb radiation from the spent fuel. Due to the presence of the ${ }^{10} \mathrm{~B}$ isotope, these stainless steels have superior neutron-absorption capabilities. ${ }^{3}$ Spent fuel rods are stored in dry casks, made up of borated stainless steel for long-term thermal neutron irradiation. Despite the fact that boron allows an adequate neutron absorption, it has an adverse influence on mechanical properties, particularly on the fracture toughness. Very low solubility of boron in an austenitic matrix results in the formation of hard, brittle $(\mathrm{Cr}, \mathrm{Fe})_{2} \mathrm{~B}$ precipitating phases, which are low-melting eutectics. ${ }^{4}$ The size, shape and distribution of these borides also deteriorate the mechanical properties. ${ }^{5}$ Park et al. ${ }^{6}$ conducted post-weld heat treatments and reported that spheroidized accicular eutectic phases were found to enhance the ductility.

Earlier, borated SSs were typically used as bolts on additions to a structural framework. However, due to the 
slow and non-automatic riveting process, welding was adopted. The solidification cracking susceptibility is high at $0.2 \%$ of mass fractions of boron due to a wider solidification range. ${ }^{7}$ In later studies, it was found that a boron content of $0.5 \%$ of mass fractions or more, i.e., above its solid-solubility limit causes a reduction in the coefficient of thermal expansion and constricts the solidification range, which, in turn, causes the crack-healing phenomenon and decreases the cracking susceptibility. ${ }^{8,9}$ The lower solidification-cracking susceptibility of high-boron steels is mainly due to the healing of cracks by the abundant amounts of the low-melting eutectic liquid of $(\mathrm{Cr}, \mathrm{Fe})_{2} \mathrm{~B} \cdot{ }^{10}$

ASTM A887-89 covers eight different types of borated stainless steels, and each type has two grades, i.e., A and B with different boron contents. ${ }^{11}$ Specification designates Grade A for the materials produced with powder metallurgy containing finer and more uniformly distributed borides compared to Grade B made with ingot metallurgy. The borated SSs fabricated with the hot-rolling technique, employing the powder-sintering method have sufficient ductility and other properties. ${ }^{12}$

The GTAW is the welding process normally used in the fabrication of borated stainless steels. However, its disadvantage is a relatively shallow penetration during a single-pass welding operation on thicker plates. The thickness of the austenitic stainless steels that can be welded in a single pass with argon as the shielding gas is normally restricted to $3 \mathrm{~mm}$. In this connection, a novel variant of the GTA welding process called the activated-flux GTA welding process was initially developed for the welding of titanium at the Paton Institute of Electric Welding. ${ }^{13,14}$ Several investigations were carried out by various researchers to develop suitable flux components to extend this technique to other alloys. In the activated-flux GTA welding process, a thin coating of the activated flux is applied onto the surface of a joint and the electrons outside the arc are captured by the flux when it is vaporized during welding. Thus, the arc gets constricted which, in turn, leads to an increase in the penetration. Sun and Pan reported that the penetration capability can be increased by as much as $300 \%$ due to the activated-flux GTA welding when compared with the conventional GTA welding. ${ }^{15,16}$

The main reasons for the significant improvement in the penetration in the steels are reported to be the arc constriction and the reversed Marangoni convection. ${ }^{17}$ However, several researchers stated that the increase in the penetration is due to the positive surface-tension gradient in a molten-weld pool, which causes the fluid to flow towards the bottom of the weld. ${ }^{18,19}$ Thus, based on the productivity, the activated GTA welding process is more viable than the conventional GTA welding process. The activated GTA welding of austenitic stainless steels was investigated by various authors to understand the effect of the flux on the depth of penetration, the aspect ratio, the microstructure and the mechanical beha vior. ${ }^{20-26}$

Furthermore, the effect of the activated flux on the GTA welding of austenitic stainless steel 316L was studied by Kuang Hung et al. ${ }^{27}$ It was reported that the activated TIG welding increases the joint penetration and the aspect ratio, which, in turn, reduce the angular distortion of the weldments. A great deal of research was carried out to develop various flux combinations and understand their beneficial influence on the GTA welding of austenitic stainless steels. Several investigations showed that an addition of nitrogen to the shielding gas influences the weld-bead shape, the depth of penetration and the weld metal microstructure..$^{28,29}$

However, not much information pertaining to the effect of the activated flux and nitrogen addition on the GTA welding of borated SS has been reported so far. Therefore, this work presents the microstructure and mechanical behavior of GTAW, activated-flux GTAW, nitrogen-added GTAW and electron-beam welding (EBW) of 10-mm-thick borated stainless steel.

\section{EXPERIMENTAL WORK}

The base material used in this study was borated stainless steel (BSS) 304B4 and its chemical composition is given in Table 1. As-received rolled plates of 40 $\mathrm{mm}$ were cut, using an electrical discharge machine to prepare plates of $300 \mathrm{~mm} \times 110 \mathrm{~mm} \times 10 \mathrm{~mm}$. The plates were cleaned using acetone to remove surface contamination before the welding.

Table 1: Chemical composition of the base material

Tabela 1: Kemijska sestava osnovnega materiala

\begin{tabular}{|c|c|c|c|c|c|c|c|}
\hline Material & $\mathrm{Cr}$ & $\mathrm{Ni}$ & $\mathrm{Mn}$ & $\mathrm{B}$ & $\mathrm{Si}$ & $\mathrm{P}$ & $\mathrm{C}$ \\
\hline 304B4 & 19.3 & 13.4 & 2.0 & 1.05 & 0.74 & 0.045 & 0.08 \\
\hline
\end{tabular}

Bead-on-plate welds were produced using the automatic GTAW process. A tungsten electrode (AWS classification EWTh-2) with a diameter of $3.2 \mathrm{~mm}$ and the shielding gas of pure argon were used in the conventional GTAW process with direct-current electrode negative (DCEN) polarity. In addition to argon-shielded bead-on-plate welds, welds were produced using a shielding-gas mixture containing $2 \%$ (volume) nitrogen along with argon. Also, autogenous full-penetration electron-beam welds were also made.

For the activated GTA welding, the activated flux was prepared, with its constituents in the required proportions, and then mixed with ethanol and the resulting mixture was stirred until it turned into paste. The flux used in this process is commercially available and its composition was reported in the patent by M.Vasudevan. ${ }^{30} \mathrm{~A}$ thin layer of this paste was applied manually on the surface to be welded and dry powder remained there after the evaporation of ethanol. Using this activated flux, several bead-on-plate experiments were 
Table 2: Common used welding parameters

Tabela 2: Uporabljeni splošni parametri varjenja

\begin{tabular}{|c|c|c|c|c|c|}
\hline $\begin{array}{c}\text { Cross-sections of the } \\
\text { welds }\end{array}$ & $\begin{array}{c}\text { Depth of } \\
\text { penetration }(\mathrm{mm})\end{array}$ & $\begin{array}{l}\text { Aspect ratio } \\
(d / w)\end{array}$ & $\begin{array}{l}\text { Weld area } \\
\left(\mathrm{mm}^{2}\right)\end{array}$ & Welding parameters & $\begin{array}{c}\text { Heat input } \\
(\mathrm{KJ} / \mathrm{mm})\end{array}$ \\
\hline & 3.8 & 0.27 & 51.45 & $\begin{array}{l}\text { Weld current: } 235 \mathrm{~A} \\
\text { Arc voltage: } 17 \mathrm{~V} \\
\text { Travel speed: } \\
120 \mathrm{~mm} / \mathrm{min} \\
\text { Gas flow rate: } \\
25,3 \mathrm{~Pa} \mathrm{~m}^{3} \mathrm{~s}^{-1}\end{array}$ & 2 \\
\hline & 5.77 & 0.4 & 57.54 & $\begin{array}{l}\text { Weld current: } 235 \mathrm{~A} \\
\text { Arc voltage: } 17 \mathrm{~V} \\
\text { Travel speed: } \\
120 \mathrm{~mm} / \mathrm{min} \\
\text { Gas flow rate: } \\
25,3 \mathrm{~Pa} \mathrm{~m}^{3} \mathrm{~s}^{-1}\end{array}$ & 2 \\
\hline & 10 & 0.8 & 92.01 & $\begin{array}{l}\text { Weld current: } 235 \mathrm{~A} \\
\text { Arc voltage: } 17 \mathrm{~V} \\
\text { Travel speed: } \\
120 \mathrm{~mm} / \mathrm{min} \\
\text { Gas flow rate: } \\
25,3 \mathrm{~Pa} \mathrm{~m}^{3} \mathrm{~s}^{-1}\end{array}$ & 2 \\
\hline & 10 & 2.82 & 17.02 & $\begin{array}{l}\text { Acceleration voltage: } \\
60 \mathrm{KV} \\
\text { Beam current: } 70 \mathrm{~mA} \\
\text { Travel speed: } \\
700 \mathrm{~mm} / \mathrm{min}\end{array}$ & 0.36 \\
\hline & & & & & \\
\hline
\end{tabular}

carried out in order to achieve a single-pass full-penetration weld in the activated GTAW process.

The parameters used in various welding processes are presented in Table 2. Using standard metallographic procedures, specimens were prepared for a microstructural investigation. After polishing, the specimens were etched with Kalling's 1 solution containing $5 \mathrm{~g}$ of cupric chloride, $100 \mathrm{~mL}$ of hydrochloric acid and $100 \mathrm{~mL}$ of ethanol. The welds were initially examined with a stereo microscope and then bead-geometry measurements were taken using image-analysis software. The microstructures of different zones of interest such as FZ, PMZ and the base metal (BM) were observed with a light microscope. Micro-hardness tests were carried out using a Vickers digital micro-hardness tester along the weld joint. A load of $500 \mathrm{~g}$ was applied for a duration of $10 \mathrm{~s}$.
In accordance with ASTM E8, tensile specimens were machined with an EDM-wire-cutting machine so that the weld metal was located in the center of gauge length. The tensile properties of weldments, i.e., the ultimate tensile strength, the proof strength and the percent elongation were evaluated on the basis of the results of the tensile tests conducted at room temperature. The tensile-test results are listed in Table $\mathbf{3}$ and all the values presented are average values of at least three specimens. Charpy-impact test specimens were prepared in accordance with ASTM standard E23. Identical V-notches were machined on three specimens, at the weld center, using a broaching machine. Impact testing was conducted at room temperature using a pendulum-type machine with the maximum capacity of $300 \mathrm{~J}$. 


\section{RESULTS}

Cross-sections of the welds made using different welding processes are presented in Table 2, along with the bead-profile parameters and corresponding welding parameters. The microstructure of the base metal is presented in Figure 1. The microstructures of FZ and PMZ for the welds made using various welding processes are shown in Figures 2a to $\mathbf{2 d}$ and Figures 3a to $\mathbf{3 d}$, respectively. The microhardness surveys carried out along the various weld zones such as FZ, PMZ and BM of different welds are shown in Figures $4 \mathbf{a}$ to $4 \mathbf{d}$. The tensile properties for the different welds considered in the

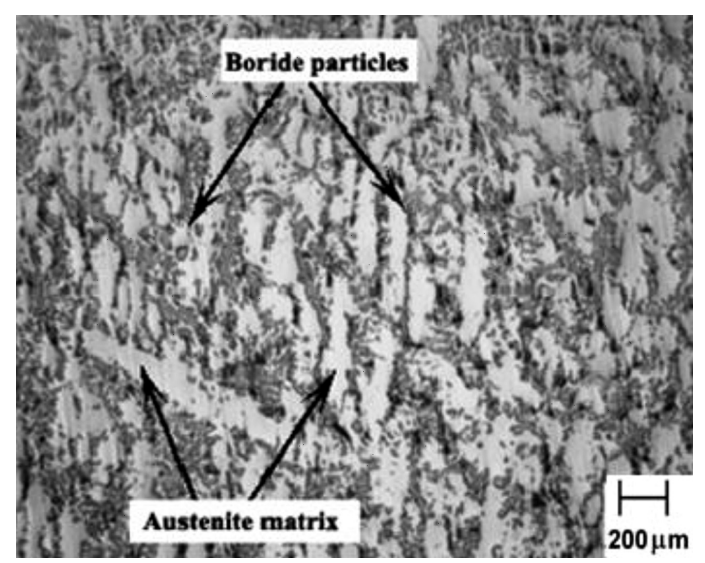

Figure 1: Microstructure of the base metal showing a boride network in an austenitic matrix

Slika 1: Mikrostruktura osnovnega materiala, ki kaže mrežo boridov v avstenitni osnovi
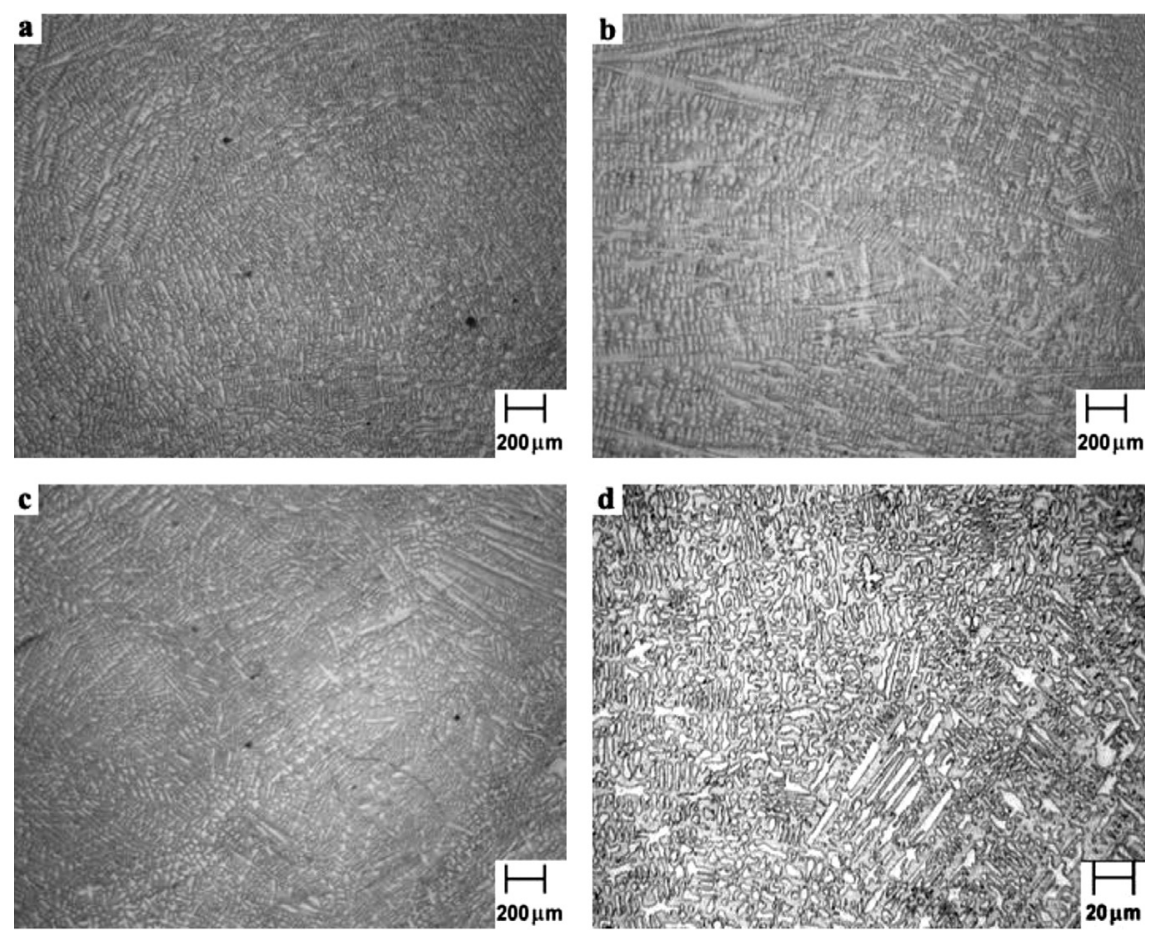

Figure 2: Microstructures of the FZs after various welding processes: a) GTAW, b) activated GTAW, c) nitrogen-added GTAW, d) EBW Slika 2: Mikrostrukture FZ pri različnih postopkih varjenja: a) GTAW, b) aktiviran GTAV, c) dušik dodan GTAW, d) EBW

present study are presented in Table 3. The results of the Charpy-impact test conducted at room temperature for the welds produced using various welding processes are presented in Table 3.

\section{DISCUSSION}

\subsection{Weld bead geometry}

From Table 2, it can be seen that the three variants of the GTA process use the same welding parameters and heat input, i.e., $2 \mathrm{~kJ} / \mathrm{mm}$. The use of $\mathrm{Ar}+2 \% \mathrm{~N}$ shielding gas in place of Ar significantly increases the depth of penetration, from $3.8 \mathrm{~mm}$ to $5.7 \mathrm{~mm}$; and the aspect ratio of the weld bead also increases. This was observed by earlier researchers for other materials. ${ }^{28,29}$ For the same heat input, the effect of the activated flux on the bead geometry is much more significant and a full penetration of $10 \mathrm{~mm}$ is observed. It can also be seen from the macrograph presented in Table 2 that the activated flux causes the aspect ratio of the weld bead to reach 0.8 , which is a significant change. Electron-beam welds exhibit the keyhole type of the bead geometry and a full penetration can be achieved using a much smaller heat input of $0.36 \mathrm{~kJ} / \mathrm{mm}$, showing the process to be greatly enhanced.

It was observed in this study that the bead shape becomes relatively wider and shallower with an increase in the welding current for both GTA and nitrogen-added GTA welding. Generally, the surface tension $(\sigma)$ on the pool surface, formed by the cohesive forces of liquid metal, decreases with an increase in the temperature. Thus, 
Table 3: Mechanical properties of 304B stainless-steel welds made with various GTA welding processes

Tabela 3: Mehanske lastnosti zvarov nerjavnega jekla 304B, izdelanih po različnih GTA varilnih postopkih

\begin{tabular}{|c|c|c|c|c|c|c|}
\hline Process & Proof strength & $\begin{array}{c}\text { Ultimate tensile } \\
\text { strength }\end{array}$ & $\%$ Elongation & $\begin{array}{c}\text { Joint efficiency } \\
\text { in terms of } \\
\text { tensile strength }\end{array}$ & Failure location \\
toughness & - & \\
\hline Base metal & 384 & 576 & 12 & - & 7 \\
\hline GTAW & 379 & 545 & 10 & 94.62 & PMZ & 7 \\
\hline Nitrogen added GTAW & 390 & 550 & 11 & 96.32 & PMZ & 8 \\
\hline Activated GTAW & 400 & 569 & 14 & 98.78 & BM & 7 \\
\hline EBW & 415 & 570 & 12 & 98.95 & BM & 10 \\
\hline
\end{tabular}
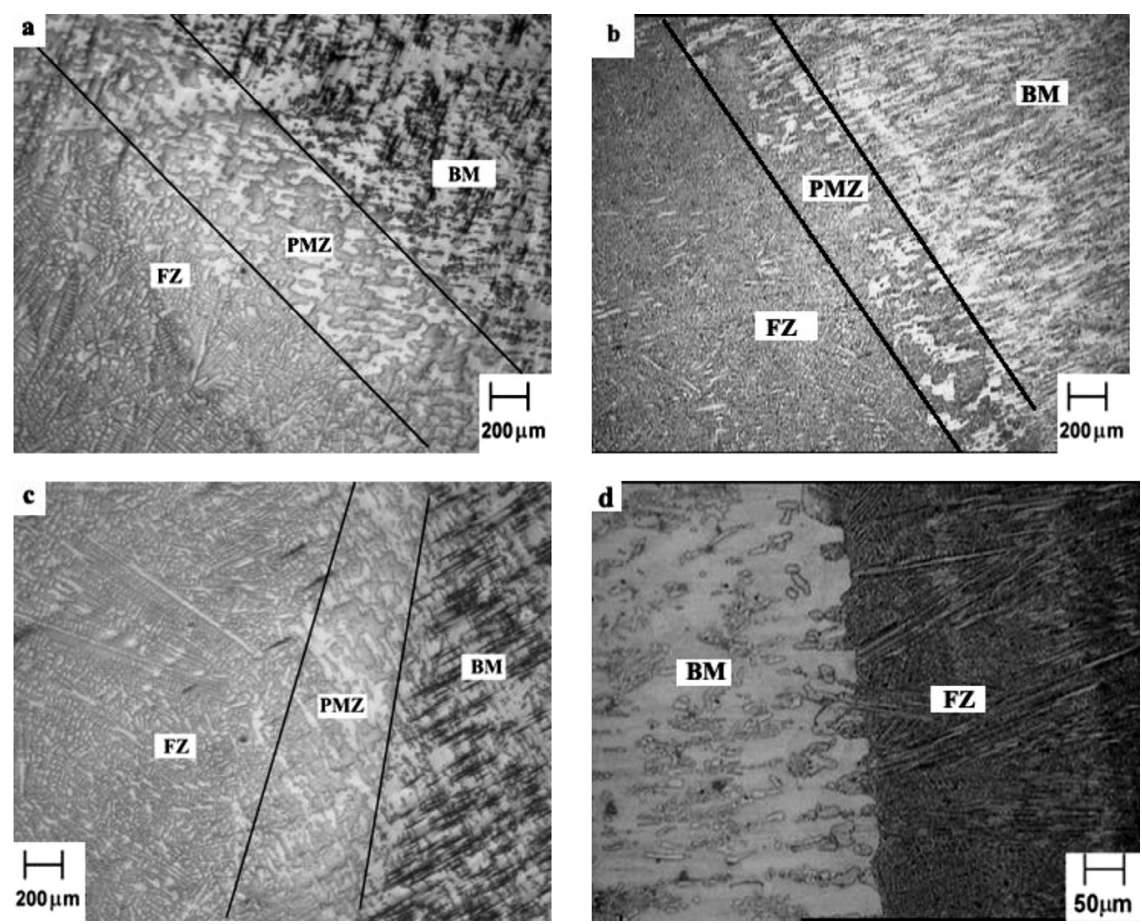

Figure 3: Microstructures of the weldments after various welding processes: a) GTAW, b) activated GTAW, c) nitrogen-added GTAW, d) EBW Slika 3: Mikrostrukture zvarov pri različnih procesih varjenja: a) GTAW, b) aktiviran GTAW, c) GTAW z dodanim dušikom, d) EBW

the temperature gradient becomes negative, i.e., $\mathrm{d} \sigma / \mathrm{d} T<0$ which, in turn, generates centrifugal Marangoni convection in the molten pool. This constitutes one of the main reasons for the shallow penetration and lower aspect ratio in the conventional GTA welding. However, in the case of activated GTA welds, the presence of the activated flux changes the temperature gradient to a positive value, i.e., $\mathrm{d} \sigma / \mathrm{dT}>0$. This positive temperature gradient causes centripetal Marangoni convection, which, in turn, directs the flow toward the pool center resulting in a deeper and narrower weld pool. By and large, it was noticed that the activated flux beneficially influenced the Marangoni convection mode by changing the temperature gradient. Furthermore, the aspect ratio was increased due to the variation in the temperature gradient. $^{21,22}$

\subsection{Microstructure}

As it can be noticed, irregular boride particles $(\mathrm{Fe}, \mathrm{Cr})_{2} \mathrm{~B}$, seen as a dark phase, are dispersed in the austenitic matrix. Boron is insoluble in austenite virtually at all temperatures. The insolubility is more significant in the case of steels with high boron levels, which, in turn, results in a continuous network of boride eutectics such as $\mathrm{Fe}_{2} \mathrm{~B}$ and $\mathrm{Cr}_{2} \mathrm{~B}$ in an austenitic matrix. The boride eutectics strengthen the austenitic matrix but adversely affect the toughness and ductility of these steels. Furthermore, the shape of these eutectic phases is also one of the factors affecting the mechanical behavior of a weld. 6

In order to have full-penetration welds for microstructural studies and an evaluation of mechanical properties, the welds were made using two passes in the case of the GTA and nitrogen-added GTA processes and a single pass in the case of the activated-flux and EB processes. The fusion zone of the activated-flux-GTA weld was characterized by a columnar, austenite dendritic structure with eutectic borides solidified in the interdendritic regions (Figure 2b). However, the GTA and nitrogen-added-GTA welds exhibited both equiaxed 

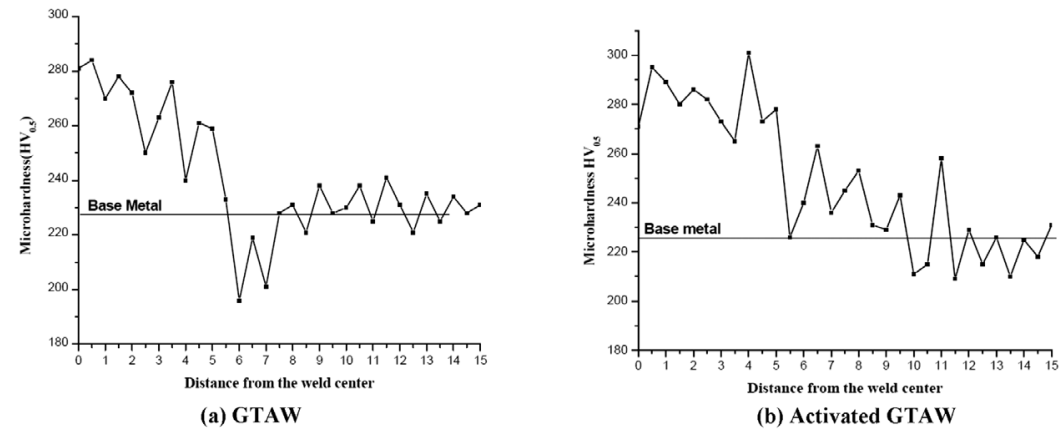

(b) Activated GTAW

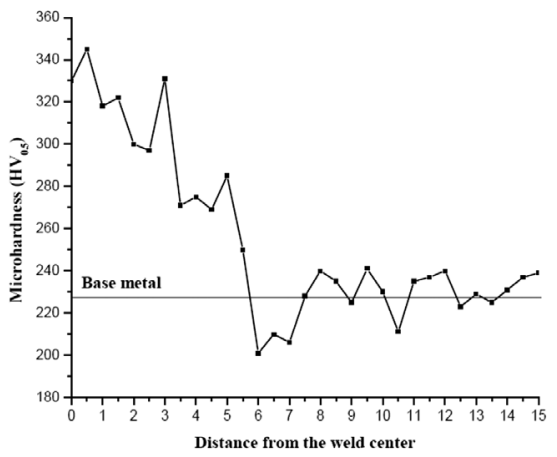

(c) Nitrogen-added GTAW

Figure 4: Microhardness profiles for various welding processes Slika 4: Profil mikrotrdote pri različnih procesih varjenja

and columnar dendritic structures, as can be seen in Figures $\mathbf{2 a}$ and $\mathbf{2 c}$. A short interaction span with an acute energy density causes a low heat input in EBW. As a result, the fusion zone in EBW cools faster resulting in a finer equiaxed dendritic structure.

Typical appearances of the PMZ for various weld types are presented in Figure 3. As it can be noticed, the representative $\mathrm{PMZ}$ consists of localized regions of austenite that remain solid during the welding, surrounded by irregular boride eutectics. However, the width of PMZ was found to be larger in the case of the GTA and nitrogen-added-GTA welds than that of the activated-flux-GTA welds. This is attributed to slow cooling rates associated with high heat inputs prevailing in the GTA and nitrogen-added-GTA welds. The low heat input associated with high cooling rates almost eliminated the PMZ in electron-beam welding and no localized region of austenite was noticed in Figure 3d.

\subsection{Mechanical properties}

\subsubsection{Microhardness}

Hardness profiles revealed that FZ exhibited a higher hardness for all the welds. The increase in the hardness of FZ is attributed to the presence of a dendritic microstructure with boride eutectics in the interdendritic regions (Figure 2). It was observed that the nitrogen addition in the GTA welds significantly enhances the FZ hardness. It was also noticed that there is a sudden fall in the hardness of PMZ in the case of both the GTA and nitrogen-added GTA welds, while there is no such trend in the activated GTA and EB welding. The significant reduction in the $\mathrm{PMZ}$ hardness is attributed to the difference in the cooling rate, which results in a variation in the size and shape of the eutectic borides formed in PMZ as can be seen from Figures 3a to 3d. It can be seen from Figure 5 that the fracture during the tensile test in the case of the GTA and nitrogen-added GTA welds, occurs in PMZ, whereas in the case of the other two welds the fracture occurs in the base materials far away from the weld metal.

\subsubsection{Tensile properties}

In order to obtain joint properties, automatic GTAW was carried out in two passes, one from each side. Though there is no significant variation in the joint efficiencies of the welds, a marginal improvement in the yield strength for the electron-beam and activated-GTA welds was noticed. The GTA and nitrogen-added-GTA welds were found to fracture at PMZ, as shown in Figure 5 , the region where a loss in the hardness can be clearly noticed due to an irregular distribution of boride eutectics. It was also observed that the activated-GTA and EB welds failed in BM. Low-heat-input welding processes exhibited a significant improvement in the tensile strength compared to high-heat-input welding process.

\subsubsection{Impact toughness}

It was observed that the welds exhibit the same toughness as that of BM, irrespective of the welding 
G. R. KUMAR et al.: EFFECT OF ACTIVATED FLUX AND NITROGEN ADDITION ON THE BEAD GEOMETRY ...

(a) Failed specimens

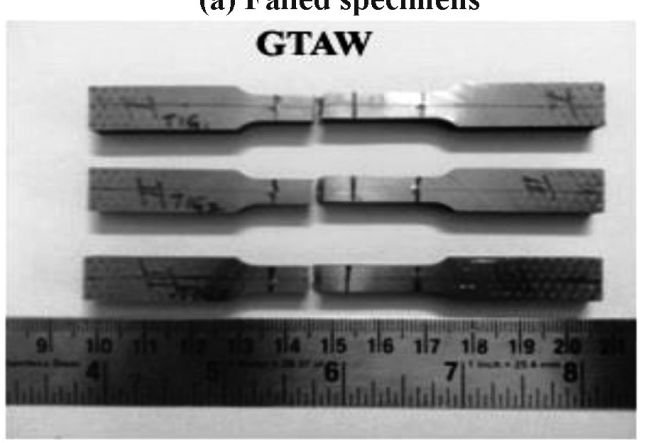

\section{activated GTAW}
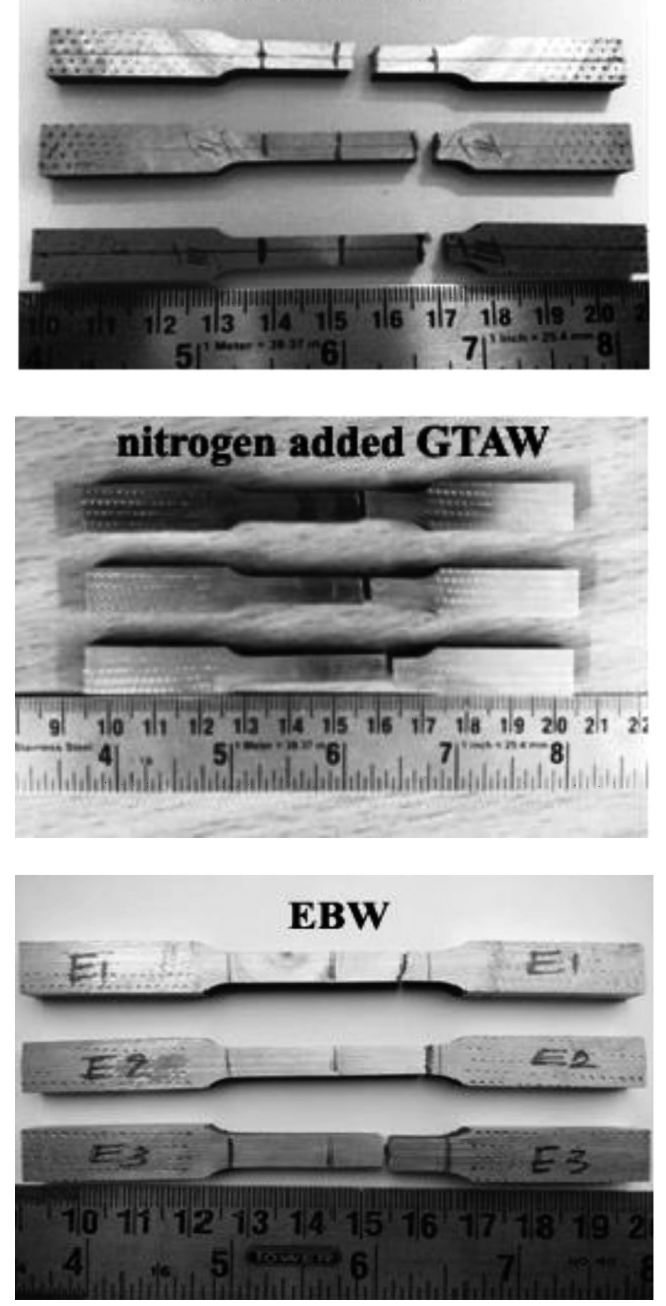

(b) Fracture locations
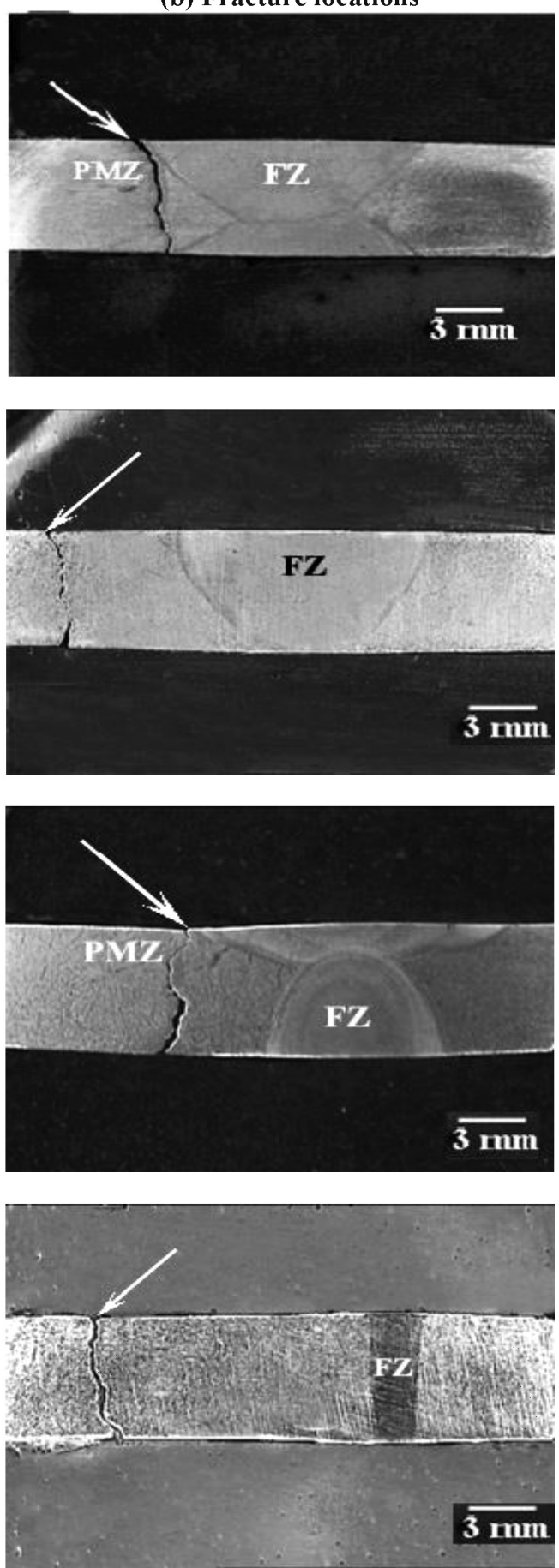

Figure 5: Fracture locations of the welds made with different welding processes: a) tensile-test samples, b) cross-sections Slika 5: Lokacija preloma zvarov, izdelanih z različnimi postopki varjenja: a) vzorci za natezne preizkuse, b) preseki

process employed. The lower toughness of $\mathrm{BM}$ and $\mathrm{FZ}$ is mainly due to brittle $(\mathrm{Cr}, \mathrm{Fe})_{2} \mathrm{~B}$ borides.

\section{CONCLUSIONS}

1. Defect-free welds of 304B4 borated stainless steels can be easily made using GTA, activated-flux GTA, nitrogen-added GTA and EB welding processes.
2. The activated-flux GTA and EB welding processes substantially enhance both the depth of penetration and the aspect ratio.

3. The fusion-zone microstructure of the activated-flux GTA welds reveals a columnar, austenite dendritic structure with eutectic borides solidified in the interdendritic regions. However, the EB welds exhibit a fine equiaxed dendritic structure. 
4. Low-heat-input EBW inhibits the formation of PMZ. A significant loss in the hardness occurs in the PMZs of the GTA and nitrogen-added GTA welds, which is mainly due to the slow cooling rates associated with high heat inputs.

5. A tensile failure occurs in the PMZ area of the GTA and nitrogen-added GTA welds, while the activated-flux GTA and EB welds failed in the base material.

\section{Acknowledgments}

The authors would like to acknowledge the technical support of IIT Madras, Defence Research \& Development Laboratory (DRDL), Hyderabad and Ador Welding Pvt. Ltd., Chennai.

\section{REFERENCES}

${ }^{1}$ C. V. Robino, M. J. Cieslak, Fusion welding of a modern borated stainless steel, Welding Journal-Including Welding Research Supplement, 76 (1997) 1, 12-23, doi:10.2172/10183280

${ }^{2}$ C. V. Robino, M. J. Cieslak, High-temperature metallurgy of advanced borated stainless steels, Metallurgical and Materials Transactions A, 26 (1995) 7, 1673-1685, doi:10.1007/BF02670754

${ }^{3}$ D. A. Moreno, B. Molina, C. Ranninger, F. Montero, J. Izquierdo, Microstructural characterization and pitting corrosion behavior of UNS S30466 borated stainless steel, Corrosion, 60 (2004) 6, 573-583, doi:10.5006/1.3287761

${ }^{4}$ H. J. Goldschmidt, Effect of boron additions to austenitic stainless steels - Part I - effect of boron additions to $20 \% \mathrm{Cr}$, $25 \% \mathrm{Ni}$ austenitic steel with and with6ut $\mathrm{Nb}, \mathrm{Mn}$ and $\mathrm{Si}$, Journal of the Iron and Steel Institute, 209 (1971) 11, 900-909

${ }^{5}$ B. Shanmugarajan, J. N. Chary, G. Padmanabham, B. Arivazhagan, S. K. Albert, A. K. Bhaduri, Studies on autogenous laser welding of type 304B4 borated stainless steel, Optics and Lasers in Engineering, 51 (2013) 11, 1272-1277, doi:10.1016/j.optlaseng.2013.05.004

${ }^{6}$ T. D. Park, K. K. Baek, D. S. Kim, PWHT effect on the mechanical properties of borated stainless steel GTA weldments for nuclear shield, Metals and Materials, 3 (1997) 1, 46-50, doi:10.1007/ BF03026105

${ }^{7}$ T. Shinoda, H. Miyake, T. Matsuzaka, T. Matsumoto, H. Kanai, Hot cracking susceptibility of boron modified AISI 304 austenitic stainless steel welds, Materials Science and Technology, 8 (1992) 10 , 913-921, doi:10.1179/026708392790169777

${ }^{8}$ W. R. Apblett, W. S. Pellini, Factors which influence weld hot cracking, Welding Journal, 33 (1954) 2, 83-90

${ }^{9}$ J. C. Borland, R. N. Younger, Some aspects of cracking in welded Cr-Ni austenitic steels, British Welding Journal, 7 (1960), 22-59

${ }^{10}$ T. Matsumoto, T. Shinoda, H. Miyake, T. Matsuzaka, H. Kanai, Effect of low-melting point eutectic on solidification cracking susceptibility of boron-added AISI 304 stainless steel welds, Welding Journal-Including Welding Research Supplement, 74 (1995), 397-405

${ }^{11}$ ASTM A887-89 (2009) ASM International, West Conshohocken, PA, USA 2009

${ }^{12}$ S. Yamamoto, M. Honda, Y. Kobayashi, T. Sakiyama, Y. Ehira, N. Takashi, Boronated stainless steels for thermal neutron shielding, Jr. Thermal \& Nuclear Power Generation, 41 (1990) 9, 1149-1157
${ }^{13}$ W. Lucas, D. Howse, Activating flux - increasing the performance and productivity of the TIG and plasma processes, Welding and Metal fabrication, 64 (1996), 11

${ }^{14}$ P. C. J. Anderson, R. Wiktorowicz, Improving productivity with A-TIG welding, Welding and Metal Fabrication, 64 (1996) 3, 108-109

${ }^{15}$ M. Vasudevan, A. K. Bhaduri, Baldev Raj, Development and evaluation of activated flux for TIG welding of type 304 LN and type 316 LN stainless steels, Proc. of the Inter. Institute of Welding, International Congress, Chennai 2008

${ }^{16}$ Z. Sun, D. Pan, Welding of titanium alloys with activating flux, Science and Technology of Welding and Joining, 9 (2004) 4, 337-344, doi:10.1179/136217104225021571

${ }^{17}$ P. Vasantharaja, M. Vasudevan, Studies on A-TIG welding of low activation ferritic/martensitic (LAFM) steel, Journal of Nuclear Materials, 421 (2012), 117-123, doi:10.1016/j.jnucmat.2011.11.062

${ }^{18}$ C. R. Heiple, J. R. Roper, Effect of selenium on GTAW fusion zone geometry, Welding Journal, 60 (1981) 8, 143-145

${ }^{19}$ C. R. Heiple, R. Roper, Mechanism for minor element effect on GTA fusion zone geometry, Welding Journal, 61 (1982) 4, 97-102

${ }^{20}$ P. Modenesi, E. R. Apolinario, TIG welding with single-component fluxes, Journal of Materials Processing Technology, 99 (2000) 1-3, 260-265, doi:10.1016/S0924-0136(99)00435

${ }^{21}$ S. Lu, H. Fujii, H. Sugiyama, M. Tanaka, K. Nogi, Marangoni convection and welding penetration in A-TIG welding, Transactions of the Japan Welding Research Institute, 32 (2003) 79-82, doi:10.1016/j.tafmec.2007.05.004

${ }^{22}$ H. Fujii, T. Sato, S. Lua, K. Nogi, Development of an advanced A-TIG (AA-TIG) welding method by control of Marangoni convection, Materials Science and Engineering A, 495 (2008), 296-303, doi:10.1016/j.msea.2007.10.116

${ }^{23}$ H. Y. Huang, S. W. Shyu, K. H. Tseng, C. P. Chou, Evaluation of TIG flux welding on the characteristics of stainless steel, Science and Technology of Welding and Joining, 10 (2005) 5, 566-573, doi:10.1179/174329305X48329

${ }^{24}$ A. Rodrigues, A. Loureiro, Effect of shielding gas and activating flux on weld bead geometry in tungsten inert gas welding of austenitic stainless steels, Science and Technology of Welding and Joining, 10 (2005) 6, 760-765, doi:10.1179/174329305X68769

${ }^{25}$ S. Leconte, P. Paillard, P. Chapelle, G. Henrion, J. Saindrenan, Effect of oxides fluxes on activation mechanisms of tungsten inert gas process, Science and Technology of Welding and Joining, 11 (2006) 4, 389-397, doi:10.1179/174329306X129544

${ }^{26}$ L. Sanbao, Y. Chunli, L. Fengyao, W. Lin, S. Sheng, Effect of activating fluxes on weld mechanical properties in TIG welding, China Welding, 10 (2001) 2, 170-174

${ }^{27}$ K. H. Tseng, C. Y. Hsu, Performance of activated TIG process in austenitic stainless steel welds, Journal of Materials Processing and Technology, 211 (2011), 503-512, doi:10.1016/j.jmatprotec.2010. 11.003

${ }^{28}$ D. D. Nage, V. S. Raja, R. Raman, Effect of nitrogen addition on the microstructure and mechanical behaviour of $317 \mathrm{~L}$ and $904 \mathrm{~L}$ austenitic stainless steel welds, Journal of Materials Science, 41 (2006) 7, 2097-2112, doi:10.1007/s10853-006-3150-5

${ }^{29}$ K. H. Tseng, C. P. Chou, The study of nitrogen in argon gas on the angular distortion of austenitic stainless steel weldments, Journal of Materials Processing and Technology, 142 (2003), 139-44, doi:10.1016/S0924-0136(03)00593-4

${ }^{30}$ An international patent Tungsten inert gas welding flux for enhancing penetration in single pass for austenitic stainless steels, patent no. PCT/IN06/00442/dt. 8/11/06 